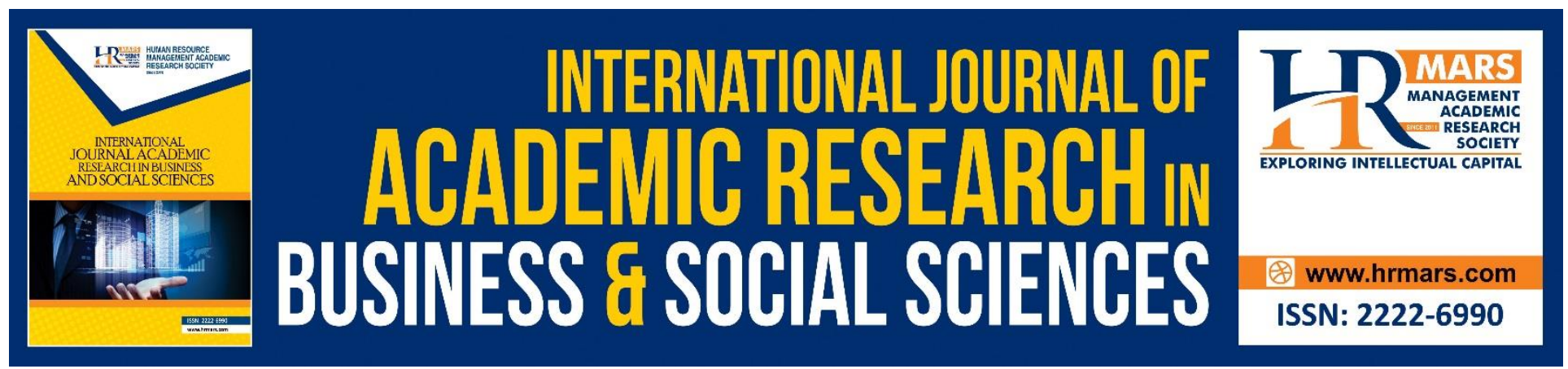

\title{
The Role of Emotional Intelligence in Work Stress and Work Performance
}

\author{
Ashim Mohd Hatta \& Nurul-Azza Abdullah
}

To Link this Article: http://dx.doi.org/10.6007/IJARBSS/v10-i10/7940

DOI:10.6007/IJARBSS/v10-i10/7940

Received: 01 August 2020, Revised: 29 August 2020, Accepted: 16 September 2020

Published Online: 20 October 2020

In-Text Citation: (Hatta, \& Abdullah, 2020)

To Cite this Article: Hatta, A. M., \& Abdullah, N-A. (2020). The Role of Emotional Intelligence in Work Stress and Work Performance. International Journal of Academic Research in Business and Social Sciences. 10(10), 274291.

Copyright: (c) 2020 The Author(s)

Published by Human Resource Management Academic Research Society (www.hrmars.com)

This article is published under the Creative Commons Attribution (CC BY 4.0) license. Anyone may reproduce, distribute, translate and create derivative works of this article (for both commercial and non-commercial purposes), subject to full attribution to the original publication and authors. The full terms of this license may be seen

at: $\underline{\text { http://creativecommons.org/licences/by/4.0/legalcode }}$

Vol. 10, No. 10, 2020, Pg. 274 - 291

http://hrmars.com/index.php/pages/detail/IJARBSS

JOURNAL HOMEPAGE

Full Terms \& Conditions of access and use can be found at http://hrmars.com/index.php/pages/detail/publication-ethics 


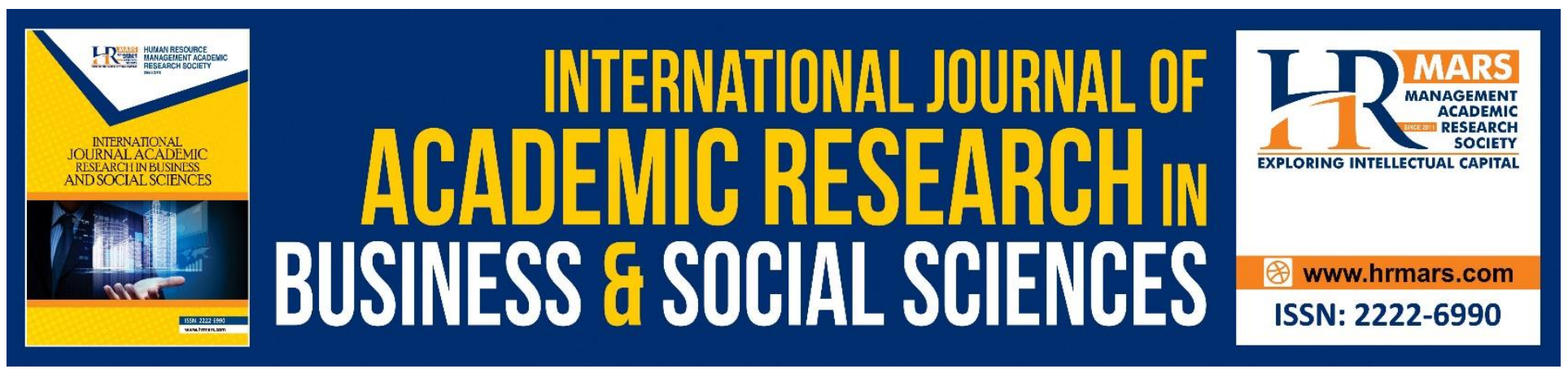

\title{
The Role of Emotional Intelligence in Work Stress and Work Performance
}

\author{
Ashim Mohd Hatta \& Nurul-Azza Abdullah \\ Psychology and Human Well-Being Research Centre, Faculty of Social Sciences and Humanities, \\ Universiti Kebangsaan Malaysia, Bangi, Selangor.
}

\begin{abstract}
Work and career as a teacher in today's day and age are increasingly challenging. Change in students' thinking and actions throughout the ages requires high levels of competence, skill and patience by teachers, who sincerely educate and build the souls of the people. Teachers are now not only burdened with teaching, they are also burdened with administrative and managerial work that inevitably causes stress and disrupts their work performance. This study aimed to identify the role of emotional intelligence as a moderator for the relationship between work stress and job performance among high school teachers serving under the education system of a private body, called IM Education. 4-part questionnaire set was used as a survey instrument for 211 secondary school teachers from 30 IM Education branch schools across Malaysia. The respondents of this study were selected using the targeted sampling method. The data were then analyzed using Statistical Package for Social Science (SPSS) software version 25. Most teachers reported moderate levels of work stress, accompanied by high work performance and also high level of emotional intelligence. Through Pearson's correlation analysis and hierarchical regression, emotional intelligence elements have successfully become a significant moderator in the relationship between work stress and job performance among respondents in this research. This finding signifies the importance of emotional intelligence elements in influencing perceptions of work pressure and work performance among educators. Emotional intelligence is a very important asset that needs to be considered and monitored as early as work selection. Researchers have also suggested several initiatives that can be done to improve teachers' emotional intelligence levels.
\end{abstract}

Keywords: Emotional Intelligence, Work Stress, Work Performance, High School Teachers, Private School.

\section{Introduction}

Stress is a psychological and physical condition that is present in everyone (Joseph, 2004). Accordingly, Mumpuni \& Wulandari (2010) say that stress is the condition of an individual who experiences an imbalance which is a dynamic condition in which an individual is in a dilemma between opportunities, guidance, or resources related to what the individual desires and the outcome. is uncertain. 
INTERNATIONAL JOURNAL OF ACADEMIC RESEARCH IN BUSINESS AND SOCIAL SCIENCES Vol. 10, No. 10, 2020, E-ISSN: 2222-6990 @ 2020 HRMARS

Further, Smith (2002) states that stress is caused by anything that makes an individual feel stressed, angry, inflamed, or unhappy. It is in the opinion of the expert that it can be concluded that stress is the condition of an individual who is experiencing an imbalance due to the incompatibility between what is desired and the fact that it is affecting the individual's behavior.

Previous studies have shown that the profession of teaching is increasingly synonymous with high pressures and workloads and has gained a place in the academic world for research (Cooper, 1995; Hart et al., 1995). A study conducted by Kyriacou and Sutcliffe (1978) found that teachers experienced emotional uncontrolled stress caused by cultural changes and constantly changing educational patterns.

According to Shah (2017), the burden of teachers' academic tasks is related to the basic tasks of teachers such as preparing a daily lesson plan (RPH), conducting the process of teaching and teaching (R\&D), writing self-reflection after completion of teaching and teaching. Accordingly, according to Ramlee (2017), teachers are responsible for preparing and reviewing student assignments as well as teacher-related tasks such as assessing and preparing test reports or semester exams for students.

Another study conducted by Sipon (2007) stated that work stress experienced by teachers placed them in emotional distress such as frustration, depression, anxiety and mental stress. Those who are constantly under pressure can surely undermine the quality of their services in education and further slow down the country's process of producing knowledgeable and highly intelligent generations.

According to Che Yaakob (1991), the extra tasks imposed on teachers - and even more so - have reduced their performance and focus on their staple tasks, namely teaching. This has directly affected the teaching and learning. If this problem persists and is left without the intervention of the school management and the attention of the ministry, then the students in the crisis will be the victims.

According to Ahmad (1998) states that their career as a teacher is increasingly a burden on their physiological and psychological aspects. In addition, according to Brother Masagus (1998) reported that 30 percent of the total 28000 educators had to take on external work and could not concentrate fully on teaching. This has been taken seriously by Utusan Malaysia reports dated September 1, 2003 stating that the National Teachers Service Union (KPPK) claims that teachers are busy attending meetings and various courses have caused teachers to feel overwhelmed with new work.

According to a press release (Kosmo, 2018), the task of teachers is increasingly challenging because they have to deal with students whose knowledge and mindset are changing and evolving over time such as the widespread use of technology so that when teachers make mistakes, it is easy to mistake them. transmitted by students on social media.

Excessive work pressure can lead to burnout. According to a study by Cormaks (2000) stated that most teachers report job stress experienced burnout at certain levels in their field of work. A study by Ghazali (1997) reported that a study conducted in Malaysia found that 38.7 per cent of teachers experienced low levels of job satisfaction due to frequent stress and lack of enthusiasm while on duty as a teacher. The findings of the study by Salwa (2006) suggest that teachers perform more non- 
academic tasks than academic tasks especially during the school holidays. In addition, teachers also have to deal with the perception of most societies that teachers are not burdened with the burden of work (Mynewshub, 2014).

Due to the high pressure of the teachers, some of them decided to end the service sooner than expected. Information from the Teacher Services Unit dated February 5, 2004, had many teachers applying for early retirement, but the ministry urged them to rethink their decision because of a lack of energy in the education sector. The high workload and stress are seen to significantly influence the performance, commitment and job satisfaction of teachers.

In addition to focusing on issues of work stress and work performance, researchers also want to look at how the elements of emotional intelligence play a role in this ongoing process. Researchers are also the birth products of the IM Education system from grade 1 to level 5 . Not only that, there are several family members of the researcher and many of the friends and friends of the researcher who are educators who are successful in the vision and mission of IM Education. Thus, this study is seen as presenting the problems that are experienced academically and thus providing a solution to this problem.

Into the IM Education network system which was the subject of the study respondents, the aforementioned issues increased in intensity. This is because besides the work assigned by the school and Ministry of Education Malaysia, teachers in the IM Education network system are also burdened with additional tasks handed down by the system management such as subjects, assessment, cocurricular activities in and out of school hours, must-do courses and more.

Researchers have also heard personally and face to face with teachers from several branches of the school in the IM Education network to hear their complaints and complaints about the school system which can be summed up in two key areas: workload and school administration issues.

As a result of the issues raised, there are several research questions raised by the researcher. The research questions identified for the study are as follows:

i. Is there a relationship between work stress and job performance among teachers.

ii. Is there a relationship between work stress and emotional intelligence among teachers.

iii. Is there a relationship between emotional intelligence and job performance among teachers.

iv. Does emotional intelligence with its role as moderator influence the relationship between work stress and job performance among teachers.

\section{Literature Review}

\section{Work Stress and Work Performance}

Previous studies on the relationship between work stress and job performance are inconsistent. Although the majority of empirical studies have shown a negative linear relationship between stress and performance (Siu, 2003; Van Dyne, Jehn, \& Cumming, 2002), there have also been studies where positive linear or $\mathrm{U}$-linked relationships have been found. 
INTERNATIONAL JOURNAL OF ACADEMIC RESEARCH IN BUSINESS AND SOCIAL SCIENCES Vol. 10, No. 10, 2020, E-ISSN: 2222-6990 @ 2020 HRMARS

In a study conducted at the MARA Gemencheh Science College, there was a significant relationship between workload and stress with teacher performance but the relationship is relatively simple. From the mean value of the item "highly motivated, dedicated and show a sense of responsibility when assigned" is 3.96. This is because according to Herzberg's theory (1959) if good environment is created, the performance of an organization will increase. According to Zainab (2015), if an organization's environment is weak then the employee's commitment to perform the task is reduced.

According to Siu (2003), work stress is an element of energy wasted by an individual who deals with stressors and thus disrupts and lowers attention and attention levels on a given task, thus negatively impacting work performance directly. Wu (2011) in his study found that work stress has a negative correlation with job performance, which he finds is consistent with previous studies (Gilboa et al., 2008; Siu, 2003; Van Dyne et al., 2002).

Furthermore, Montgomery, Blodgett \& Barnes (1996) through their research have identified that work stress can have a significant impact on an individual's life and career in the organization because work stress has its own role in lowering motivation and job performance, as well as improving work motivation. job exchange rate.

In addition, a study conducted by Roring, Soegoto and Dotulong (2014) on 60 government officials in North Sulawesi, Indonesia found that there is a significant impact of work stress on job performance where the focus of this study is on work load and environment or network an employee's relationship can have an impact on his or her work.

In addition, a study conducted by Pflanz and Ogle (2006) on 800 air force personnel in Wyoming, USA found that work stress had reduced the productivity of its members, inability to complete work assigned in a given period, and increased absenteeism to workplace. It is also a major factor in increasing workplace accidents.

Another study of the same theme, conducted by Suandi, Ismail and Othman (2014) of the Northern Department of Education from Perlis, Kedah and Penang with respondents of 168 staff, found that moderate and normal stress levels were still able promising good and excellent work. Low stress levels do not show the same pattern.

In Pakistan, a study conducted by Zafar et al. (2015) in the industrial sector with respondents of 200 workers showed a similar pattern in the relationship between stress and work performance, where moderate levels of stress still help workers maintain productivity and performance.

Another study in Pakistan by Ali et al. (2014) on 133 employees at a private university in Karachi found that stress arising from work load, role conflict and unfair pay with workload negatively impacted less efficient and unsatisfactory work.

A study by Vijayan (2017) on 200 workers at a dairy processing plant in Coimbatore, India, studied the impact of stress on factors of work load, job security, work conflict, job autonomy and low pay, and how it affects performance. work. Researchers have found that work stress has a significant 
INTERNATIONAL JOURNAL OF ACADEMIC RESEARCH IN BUSINESS AND SOCIAL SCIENCES Vol. 10 , No. 10, 2020, E-ISSN: 2222-6990 @ 2020 HRMARS

relationship with job performance. However, it should be at a moderate level. If stress is at a high level and critical, job performance will decline.

However, a study by Rizwan, Waseem and Bukhari (2014) on 150 employees of various sectors did not show a common pattern of relationship where the relationship between work stress and job performance was not significant. However, in this study, work stress with job satisfaction showed a negative relationship where stress contributed $28 \%$ to job satisfaction. Similarly, a study by Nart and Batur (2014) on 266 primary school teachers in South Marmara, Turkey also showed a similar pattern of relationship where work stress did not have a significant impact on teachers' job performance.

\section{Work Stress and Emotional Intelligence}

Emotional intelligence is often associated with the perception of stress in a person. In fact, many researchers have suggested that it can be a moderation of the effects of stress on an organization (Ivancevich \& Matteson, 1980; Parker \& DeCotiis, 1983). Jamal (2005) points out that the higher the imbalance between an individual's ability and the organization's needs, the higher the level of stress experienced by the individual. Jamal also pointed out that among the skills needed for each and every employee is a modest or high emotional intelligence competency.

A study conducted by Landa, Lopez-Zafra, Martos and Aguilar-Luzon (2007) on 180 nurses at a public hospital in Spain found that nurses with high emotional intelligence scores reported lower stress levels than nurses with low emotional intelligence scores. The length of service and experience of a nurse also determines the degree of stress experienced in this study.

In addition, retrospective studies of 178 similar academic and general staff at several universities in Australia (Gillespie et al., 2001), 320 retail store managers in the United Kingdom (Slaski \& Cartwright, 2002) and 212 professionals in mental health institutions in Greece (Nikolau \& Tsaosis, 2002), all of these studies showed that employees who were able to use and regulate their own emotions and colleagues' emotions reported lower levels of physiological and psychological stress.

In addition, a study conducted by Chang (2009) on 409 semi-conductor workers at Hsinchu Science Park, China found that work stress can be controlled and regulated by intensity and intensity through emotional intelligence levels that play a significant role in the workplace.

A study by Coetzee and Harry (2014) on 409 online financial services operators in Africa showed that emotional intelligence contributes significantly to job adjustment. Work stress is one of the elements in the construction.

In line with that, Karimi et al. (2014) performed an analysis of 312 nurses in community clinics and the results showed that emotional intelligence plays a significant role in nurses' daily exposure to stress arising from nursing insufficiency, clinical management and patient outcomes. Furthermore, in a study conducted by Newton et al. (2016) of 306 professional nurses in Australia. They found that emotional intelligence also had a negative relationship with work stress. 
INTERNATIONAL JOURNAL OF ACADEMIC RESEARCH IN BUSINESS AND SOCIAL SCIENCES Vol. 10, No. 10, 2020, E-ISSN: 2222-6990 @ 2020 HRMARS

Emotional intelligence can not only control the effects of stress at work, but it can reduce stress and resilience. This is reflected in a study by Wan, Downey and Stough (2014) on 184 employees from various sectors in Australia.

A study by Min (2014) on 484 tour guides in Taiwan reported that employees with high emotional intelligence, less exposed and exposed to stress at work. In this sector, stress management is crucial in ensuring the quality of service to tourists.

\section{Emotional Intelligence and Work Performance}

Individuals with high emotional intelligence, have sufficient capacity to effectively identify, regulate and use their own emotions in their surrounding relationships (Salovey \& Mayer, 1990). According to Goleman (1998), he argues that emotional intelligence is one of the determinants of work performance and that it also has a positive correlation with the success of an individual in the organization. Besides the job performance, a lot of the researcher conducted a study on the relationship between emotional intelligence and management and leadership skills.

According to King and Gardner (2006), they state that competence and emotional intelligence have been identified as key factors contributing to job performance in various occupations. Higgs (2004), in a study of online customer service workers in the United Kingdom, found that emotional intelligence has a high correlation in determining an employee's job performance.

Carmeli (2003) in her study found that individuals with high levels of emotional intelligence can control and regulate their own emotions and also have competence in managing others and maintaining interpersonal relationships. In addition, he said, employees with high emotional intelligence are generally aware and able to manage their emotional states in an effort to maintain a stable and positive mental state, thus impacting positive developments in their work performance.

Emotional intelligence can not only be an determinant of an employee's achievement, it can also enhance the self-efficacy and behavior of organizational honor and serve as a buffer or moderator of the impact of burnout among employees. This is according to a study conducted by Cohen and Abedallah (2015) on 221 Arab teachers in Israel.

In a study conducted by Slaski and Cartwright (2002), they found that emotional intelligence can affect an individual's response and his or her ability to cope with organizational needs. Wu (2011) in his study of the financial sector in Taiwan found that there is a positive relationship between emotional intelligence and job performance. Wu's (2011) study can be drawn from studies of similar themes using samples in Western countries such as those by (Higgs, 2004).

In addition, an analysis by Greenidge, Devonish and Alleyne (2014) on 222 employees from 5 organizations - manufacturing, finance, services, private and public sectors in the Caribbean islands. They found that emotional intelligence plays a role in improving employee contextual performance, job satisfaction and emotional control. 
INTERNATIONAL JOURNAL OF ACADEMIC RESEARCH IN BUSINESS AND SOCIAL SCIENCES Vol. 10, No. 10, 2020, E-ISSN: 2222-6990 @ 2020 HRMARS

Similarly, Meisler and Vigoda-Gadot (2014) in their study of 368 financial company employees in Israel, found that emotional intelligence was a key element in ensuring political health in the workplace. In fact, it is a determinant of job satisfaction, job change intentions and level of employee neglect.

Further, a study by Mohammad and Jais (2016) on 212 teachers from 6 secondary schools in Kedah. They can identify that emotional intelligence through its four elements namely self-regulation, emotional awareness, self-motivation and social skills can predict a teacher's performance where the higher the emotional intelligence, the higher the achievement and achievement.

In addition, Sony and Mekoth (2016) in their study of 517 workers of electric utility operators in India, successfully validated the theory that emotional intelligence is capable of job performance, job satisfaction and adaptation throughout a career.

\section{Emotional Intelligence Moderating the Relation}

In a study by King \& Gardner (2006), they found that individuals with high levels of emotional intelligence were more likely to understand emotional states through their cognitive assessments, and then they used strategies that involved social resources as well as expressing professional feelings in a stressful work environment, the highest. According to them, high emotional intelligence can also be linked to an individual's endurance and adaptability.

Wu (2011) in his study stated that emotional intelligence can be a moderator in the relationship between work stress and job performance. Stress, he says, does not necessarily come from the source of the pressure itself, but it also affects the perception of the individual.

He also found that workers with low or high levels of emotional intelligence were better able to reduce or transform the negative effects of work stress on job performance, compared to workers with low emotional intelligence. From the results of this study, individuals with low levels of emotional intelligence were also unable to cope with stressful situations at work.

In addition, a study conducted by Yozgat, Yurtkoru \& Bolginoglu (2013) on 424 public sector workers in Istanbul found that employees with high levels of emotional intelligence were able to maintain work performance according to company standards despite the stressful work environment. the highest.

Similar themes have been researched on 178 academic and general staff at several Australian universities (Gillespie et al., 2001), 320 retail store managers in the United Kingdom (Slaski \& Cartwright, 2002) and 212 professionals in mental health institutions in Greece (Nikolau \& Tsaosis, 2002), all of these studies show that stress controlled through moderate or high levels of emotional intelligence, can assist employees in regulating their emotions and at work. As a result, it helps to improve job performance.

Furthermore, a study conducted by Cohen and Abedallah (2015) on 221 Arab teachers in Israel found that emotional intelligence can not only be an determinant of a worker's achievement, but it is can 
INTERNATIONAL JOURNAL OF ACADEMIC RESEARCH IN BUSINESS AND SOCIAL SCIENCES Vol. 10, No. 10, 2020, E-ISSN: 2222-6990 @ 2020 HRMARS

improve the self-efficacy and behaviour of organizational honour and serve as a buffer or moderator of the impact of burnout among employees.

One of the contributors to stress in the workplace is the inability of an employee to adapt himself or herself to the environment. However, with emotional intelligence, it can be a moderation and play a role in an employee. This was analyzed by Sony and Mekoth (2016) in a study of 517 electric utility operator workers in India, who studied the role of emotional intelligence in predicting employee adaptation, job performance and job satisfaction.

Accordingly, a study by Ranashinge et al. (2017) on 471 medical students at the University of Colombia, Sri Lanka, found that a student's emotional intelligence score could predict whether or not he or she could progress through the final year. It is also capable of moderating the life of a medical student who is full of stress and inflammation.

According to Rezvani and Khosravi (2019) in their study of 363 computer software developers in Australia, they also found the same pattern where emotional intelligence can help workers regulate stress in the workplace and increase their productivity and work performance. In fact, it is also an added value in a work environment where healthy and competitive relationships can be built.

In another study by Sharma, Dhar and Tyagi (2015), they analyzed 693 nursing staff in Uttarakhand, India and it can be concluded that a nurse's emotional intelligence score predicts his or her performance, can play a role in work conflict and afford regulate their psychological health and wellbeing.

\section{Methodology}

The sampling method used by the researcher in the process of collecting research information and the results of the questionnaire is simple and objective sampling. Sampling is easy to use because researchers have easy access to respondents. Whereas sampling is intended to meet the sampling criteria of secondary school teachers under the IM education system throughout Malaysia. The researcher selected 169 teachers as the study sample based on Krejcie and Morgan's (1970) sample size that listed the sample size corresponding to the study population size.

This study used a set of questionnaires containing four (4) sections in alphabetical order, A, B, C and $D$ to carry out the measurement. Section A covers the demographic characteristics of the subject. The next three (3) sections are Occupational Stress Indicator (OSI) questionnaires by Cooper, Sloan and Williams (1988), Work Perception Perceptions questionnaire developed by Fatimahwati and Herman (1997) and Emotional Intelligence Scale developed by Wong and Law (2002).

\section{Results}

\section{There is a Significant Relationship Between Work Stress and Job Performance.}

The results of the correlation analysis between work stress variables and job performance are shown in Table 1. The analysis using Pearson correlation coefficient found that Working Pressure correlated negatively and significantly with Work Performance with a correlation value of $r=-0.214$. The relationship was significant at $p<0.05=0.02$. The results of this analysis show that the higher a teacher's job stress score, the lower his or her job performance score. Therefore, the null hypothesis 
INTERNATIONAL JOURNAL OF ACADEMIC RESEARCH IN BUSINESS AND SOCIAL SCIENCES Vol. 10, No. 10, 2020, E-ISSN: 2222-6990 @ 2020 HRMARS

is rejected. It can be concluded that the relationship between work stress and job performance is significant.

Table 1: Correlation of work stress with job performance

\begin{tabular}{llcc}
\hline & & Work Stress & Work Performance \\
\hline \multirow{3}{*}{ Work Stress } & Korelasi Pearson & 1 & $-\mathbf{0 . 2 1 4}$ \\
& Sig. (2-tailed) & & 0.002 \\
& $\mathrm{~N}$ & 211 & 211 \\
\hline \multirow{3}{*}{ Work Performance } & Korelasi Pearson & -0.214 & 1 \\
& Sig. (2-tailed) & 0.002 & 211
\end{tabular}

Table 1 explains that work pressure contributes $46 \%$ with the value of $R 2=0.46$ to the variance of work performance. Statistically the model satisfies the regression equation significantly based on ANOVA table F value $(1,209)=10.067, p<0.000$. This simple regression analysis was used to predict the effect of work stress on job performance. Job performance is predicted at $5.285+-0.209$ (job pressure). Job performance decreased significantly by 0.209 for each job pressure unit increase. Therefore, Based on the findings of this analysis the researchers conclude that there is a direct effect of work pressure on work performance

There is a Significant Relationship Between Work Stress and Emotional Intelligence.

The results of the correlation analysis between work stress variables and emotional intelligence are shown in Table 2. The analysis using Pearson's correlation coefficient found that Working Pressure correlated negatively and significantly with emotional intelligence with a correlation value of $r=$ 0.317 . The relationship was significant at $p<0.05=0.02$. The results of this analysis indicate that the higher a teacher's job stress score, the lower his or her emotional intelligence score. Therefore, the null hypothesis is rejected. It can be concluded that the relationship between work stress and emotional intelligence is significant.

Table 2: Correlation of work stress with emotional intelligence

\begin{tabular}{llrr}
\hline & & Work Stress & Emotional Intelligence \\
\hline \multirow{2}{*}{ Work Stress } & Korelasi Pearson & 1 & $-\mathbf{0 . 3 1 7}$ \\
& Sig. (2-tailed) & & 0.000 \\
& $\mathrm{~N}$ & 211 & 211 \\
\hline \multirow{2}{*}{$\begin{array}{l}\text { Emotional } \\
\text { Intelligence }\end{array}$} & Korelasi Pearson & -0.317 & 1 \\
& Sig. (2-tailed) & 0.000 & \\
& $\mathrm{~N}$ & 211 & 211 \\
\hline
\end{tabular}


INTERNATIONAL JOURNAL OF ACADEMIC RESEARCH IN BUSINESS AND SOCIAL SCIENCES Vol. 10, No. 10, 2020, E-ISSN: 2222-6990 @ 2020 HRMARS

Table 2 explains that emotional intelligence contributes $10 \%$ with the value of R2 $=0.10$ to the working pressure variance. Statistically this model satisfies the regression equation significantly based on ANOVA table F value $(1,209)=23.368, p<0.000$.

This simple regression analysis was used to predict the influence of emotional intelligence on work stress. Work stress is predicted at $4.295+-0.264$ (emotional intelligence). Working stress decreased significantly by 0.264 for each increase in emotional intelligence units. Therefore, based on the findings of this analysis the researchers conclude that there is a direct effect of emotional intelligence on work stress.

\section{There is a Significant Relationship Between Emotional Intelligence and Job Performance}

The results of the correlation analysis between work stress variables and emotional intelligence are shown in Table 3. The analysis using Pearson's correlation coefficient found that emotional intelligence was positively and significantly correlated with job performance with a correlation value of $r=0.715$. The relationship was significant at $p<0.05=0.02$. The results show that the higher the teacher's emotional intelligence score, the higher his or her performance score. Therefore, the null hypothesis is accepted. It can be concluded that the relationship between emotional intelligence and job performance is significant.

Table 3: Correlation of emotional intelligence with work performance

\begin{tabular}{llcc}
\hline Pemboleh Ubah & & $\begin{array}{c}\text { Emotional } \\
\text { Intelligence }\end{array}$ & Work Performance \\
\hline $\begin{array}{l}\text { Emotional } \\
\text { Intelligence }\end{array}$ & Korelasi Pearson & 1 & $\mathbf{0 . 7 1 5}$ \\
& Sig. (2-tailed) & & 0.000 \\
\hline \multirow{3}{*}{ Work Performance } & Korelasi Pearson & 211 & 211 \\
& Sig. (2-tailed) & $\mathbf{0 . 7 1 5}$ & 1 \\
& $\mathrm{~N}$ & 0.000 & 211 \\
\hline
\end{tabular}

Table 3 explains that emotional intelligence contributes $51 \%$ with a $R 2=0.51$ value of work performance variance. Statistically this model satisfies the regression equation significantly based on ANOVA table F value $(1,209)=47.665, p<0.000$.

This simple regression analysis was used to predict the influence of emotional intelligence on job performance. Job performance is predicted at $1.576+0.580$ (emotional intelligence). Job performance increased significantly by 0.580 for each increase in emotional intelligence units. Therefore, based on the findings of this analysis the researchers conclude that there is a direct effect of emotional intelligence on work performance. 
INTERNATIONAL JOURNAL OF ACADEMIC RESEARCH IN BUSINESS AND SOCIAL SCIENCES Vol. 10, No. 10, 2020, E-ISSN: 2222-6990 @ 2020 HRMARS

\section{Emotional Intelligence Acts as a Moderator in The Relationship Between Work Stress and Job Performance}

The researchers used hierarchical regression analyzes on the recommendations of Yu-Chi Wu (2011) and Yozgat et al. (2013) using the same study model as the researcher. Based on the model summary in Model 1 shows that work pressure contributed $46 \%$ with a value of R2 $=0.46$. Whereas in Model 2 , the amount of R2 increased to 0.511 when the element of emotional intelligence was included.

In the results of ANOVA analysis, the change in F value from Model 1 from 10.067 to 108,686 in Model 2 indicates the significance of emotional intelligence presence in the relationship between work stress and job performance. This very large change in value reflects the persistence of emotional intelligence as a moderator. This is more evident in the coefficients, the B value in model 1 is $5.285+$ -0.209 , whereas in Model 2 there are significant and significant changes where the $B$ value model changed to $1.518+0.013+0.584$ when emotional intelligence was included in this analysis. It can be concluded that emotional intelligence successfully acts as a moderator or moderator of the effects of the relationship between work stress and job performance.

\section{Discussion}

\section{Work Stress and Work Performance}

Previous studies on the relationship between work stress and job performance are inconsistent. The majority of empirical studies have shown a negative linear relationship between job stress and job performance (Siu, 2003; Van Dyne, Jehn, \& Cumming, 2002). The results show that this is in line with the findings of previous studies.

The results show that there is a negative correlation with significant relationship between work stress and job performance with a correlation value of $r=-0.214$. The relationship was significant at $p<0.05$ $=0.02$. The higher the pressure on employees, the lower their performance. Vice versa. From the regression analysis, job performance is predicted to be $5.285+-0.209$ (job pressure). Job performance decreased significantly by 0.209 for each job pressure unit increase.

From this finding, work stress can disrupt the focus and equilibrium of an employee's mental wellbeing. If they are in a state of instability, they will not be able to meet the goals set by the organization and function effectively. Looking at the work patterns of teachers and educators, they are often faced with changes in educational policies that may require time to adapt. This can contribute to stress at work.

The negative relationship between work stress and job performance as a result of this study is also in line with the findings of Montgomery, Blodgett \& Barnes (1996). They recognize that work stress can have a significant impact on an individual's life and career in the organization because it has its own role in decreasing motivation and job performance, as well as improving job exchange rates.

In addition, the findings of this study are also supported by a study conducted on 800 air force personnel in Wyoming, United States by Pflanz and Ogle (2006). The results of their study show that work stress has a direct impact on soldier productivity. Not only that, they are also seen as unable to 
INTERNATIONAL JOURNAL OF ACADEMIC RESEARCH IN BUSINESS AND SOCIAL SCIENCES Vol. 10, No. 10, 2020, E-ISSN: 2222-6990 @ 2020 HRMARS

complete the work assigned within the stipulated period, increasing rates of absenteeism and increasing accidents in the workplace.

According to Glazer and Beehr (2005), work stress not only directly impacts on job performance, it is also a major contributor to other adverse effects such as fatigue, lack of motivation in the workplace, increased employee turnover, organizational dissatisfaction and less. punctual. In addition, work stress can also weaken workers' ability to make decisions.

As a result, workers are less motivated to make initiatives and innovations in the workplace. Work stress directly affects employee behavior.

\section{Work Stress and Emotional Intelligence}

Previous studies in identifying the relationship between work stress and emotional intelligence have been consistent (Cobb and Mayer; 2000; Savickas and Porfelli; 2012; Landa et al., 2007; Nikolau and Tsausis, 2002; Chang, 2009; Slaski and Cartwright, 2012 ). The results of this study show similar results to previous studies.

The analysis using Pearson correlation coefficient found that work stress was negatively and significantly related to emotional intelligence with a correlation value of $r=-0.317$. The results of this analysis indicate that the higher a teacher's job stress score, the lower his or her emotional intelligence score. Vice versa. Through regression analysis, job stress was predicted with $4.295+-$ 0.264 (emotional intelligence). Working stress decreased significantly by 0.264 for each increase in emotional intelligence units.

Economic uncertainty has a direct impact on work patterns and demands, which in turn creates stress and job stress. In the context of teachers, the overlap of assignments, inadequate supply, cost and attitude of students across generations and adaptation to the educational environment and policies can contribute significantly to the mental stability of teachers. This requires a good attitude, so emotional intelligence is seen as an effective force.

Several empirical studies (Brunetto et al., 2012; Karimi et al., 2014; Kaur et al., 2013) have identified that individuals with high levels of emotional intelligence also have low levels of burnout, engagement in the workplace higher and better psychological health. Emotional intelligence also gives an employee the ability to effectively deal with situations contributing to stress and reporting good job satisfaction and general well-being in the workplace.

The negative relationship derived from the results of this study can be supported by a study conducted on 180 nurses in a public hospital in Spain by Dutch, Lopez-Zafra, Martos and AguilarLuzon (2007). They found that nurses with high emotional intelligence scores reported lower levels of stress than nurses with low emotional intelligence scores.

Even researchers can see the same pattern of relationships in previous studies that examine the same theme; 1) 178 academic and general staff at several universities in Australia (Gillespie et al., 2001); 2) 320 retail store managers in the United Kingdom (Slaski \& Cartwright, 2002); 3) and 212 
INTERNATIONAL JOURNAL OF ACADEMIC RESEARCH IN BUSINESS AND SOCIAL SCIENCES Vol. 10, No. 10, 2020, E-ISSN: 2222-6990 @ 2020 HRMARS

professionals in mental health institutions in Greece (Nikolau \& Tsaosis, 2002). All of these studies show that employees who are able to use and regulate their own emotions and colleagues' emotions report lower levels of physiological and psychological stress.

Findings with similar tones can also be seen through the study by Karimi et al. (2014). They conducted an analysis of 312 nurses at community clinics and as a result, they found that emotional intelligence played a significant and significant role in nurses' daily exposure to stress arising from nursing insufficiency, clinical management and patient outcomes. In addition, the study by Newton et al. (2016) of 306 professional nurses in Australia. They found that emotional intelligence also had a negative relationship with work stress.

\section{Emotional Intelligence and Work Performance}

Individuals with high emotional intelligence, have sufficient capacity to effectively identify, regulate and use their own emotions in their surrounding relationships (Salovey \& Mayer, 1990). According to Goleman (1998), emotional intelligence is one of the determinants of job performance and it also has a positive correlation with the success of an individual in the organization. Research in the relationship between emotional intelligence and job performance it shows a consistent relationship (Higgs, 2004; Carmeli, 2003; Slaski and Cartwright, 2002; Wu, 2011). The results of this study show the same pattern as previous studies.

The analysis using Pearson correlation coefficient found that emotional intelligence was positively and significantly correlated with job performance with a correlation value of $r=0.715$. The results show that the higher the teacher's emotional intelligence score, the higher his or her performance score. As a result of regression analysis, job performance was predicted with $1.576+0.580$ (emotional intelligence). Job performance increased significantly by 0.580 for each increase in emotional intelligence units.

Emotional intelligence is often associated with job performance because of the nature of the work itself that requires interpersonal interaction. Most of these interactions are directly related to workrelated issues. In the context of teachers, it can be said that all corners of their careers are in direct contact with human beings, students, parents and even their own teachers. Teachers who have moderate emotional intelligence are able to identify and respond appropriately to the human emotions around them. In fact, they can also provide emotional support to colleagues who are depressed and inflamed.

According to Wong and Law (2002), employees with high emotional intelligence are able to regulate their emotions in stressful situations, thus interacting professionally and effectively in meeting job demands even under stress. According to Carmeli and Josman (2006), employees with a high level of emotional intelligence can contextually improve their quality and performance because they are able to understand and adapt to the norms and culture of an organization, seen as having no problem in adhering to the rules and having high sensitivity. high in the atmosphere and work environment.

The positive relationship between the results of this study has a similar tone to that of Slaski and Cartwright (2002). According to them, emotional intelligence can affect an individual's response and 
INTERNATIONAL JOURNAL OF ACADEMIC RESEARCH IN BUSINESS AND SOCIAL SCIENCES Vol. 10 , No. 10, 2020, E-ISSN: 2222-6990 @ 2020 HRMARS

his or her ability to cope with organizational needs. The same finding can be seen through the study by $\mathrm{Wu}$ (2011).

\section{Emotional Intelligence a Moderator}

Recent studies have shown consistent patterns in the results of emotional intelligence analysis as moderators in the relationship between work stress and job performance (Wu, 2011; Yozgat, Yurtkoru \& Bolginoglu, 2013; King and Gardner, 2006). This study also shows the same pattern of results as previous studies.

Through hierarchical regression analysis, researchers can conclude that emotional intelligence has successfully played a role in moderating the relationship between work stress and job performance significantly. The presence of emotional intelligence in the relationship showed a decrease in the impact of work stress and an increase in job performance among IM Education system teachers who were respondents in this study.

The results of this study show that emotional intelligence can act as a moderator according to the study conducted by Wu (2011). He found that workers with low or high levels of emotional intelligence were better able to reduce or transform the negative effects of work stress on job performance, compared to workers with low emotional intelligence.

In addition, the researcher was also able to identify similar patterns of relationship from the study by Yozgat, Yurtkoru \& Bolginoglu (2013). They found that employees with high levels of emotional intelligence were able to maintain work performance according to company standards even in a high stressful work environment. Emotional intelligence is known to enhance the self-efficacy and behavior of organizational well-being and to serve as a buffer or moderation of the impact of burnout among workers according to a study conducted by Cohen and Abedallah (2015) on 221 Arab teachers in Israel.

Not only that. The study by Ranashinge et al. (2017) also show a similar relationship pattern. A study conducted on 471 medical students at the University of Colombia, Sri Lanka, found that one's emotional intelligence scores the student can predict whether or not the student will progress through the final year.

In fact, stress does not stem from the source of the stress itself, but rather to the individual's perception. Thus, in this study, individuals with adequate emotional intelligence had the ability to reduce or transform the negative effects experienced at work to improve their work performance or to moderate their effect to a reasonable extent, compared to individuals with low emotional intelligence. Workers with low emotional intelligence are less likely to interact with stressful situations and manage their emotions and actions professionally.

From this study we can also see that work pressure factors are not caused solely by one's external factors but are also influenced by one's internal factors. Therefore, the level of pressure faced by each individual varies by the extent to which he or she perceives the pressure to be affected. 
INTERNATIONAL JOURNAL OF ACADEMIC RESEARCH IN BUSINESS AND SOCIAL SCIENCES Vol. 10, No. 10, 2020, E-ISSN: 2222-6990 @ 2020 HRMARS

\section{Conclusion}

Overall, work stress and intelligence The results of this study have shown significant influence on the three variables of the study. These three variables are an important element of a teacher's career. The controlled interactions between these three elements can promise promising results.

This career as a teacher is synonymous with work stress. Present teachers are burdened with administrative and clerical tasks, mentoring to student groups, co-curricular advisors such as associations, sports, uniformed units, updating student data. Not only that, teachers also have to prepare daily lesson plans (RPHs), conduct the learning and teaching (R\&D) processes, write selfreflection after the completion of the teaching and teaching. If we bring it into the context of teachers in the IM Education system, the burden of a teacher will increase with the demands and goals that IM Education places within the scope of a teacher's job.

Modules and assessments assigned to a teacher need to be studied not only theoretically, but more importantly, the practical aspects and the implementation itself according to a teacher's schedule and life. In addition to work stress, this study also focused on emotional intelligence. This issue is the main topic of this study because a teacher is often exposed to negative emotions when interacting with their students, colleagues, schoolmates and supervisors. So it is not surprising to emphasize that emotional demands are considered to be the greatest threat ( $s$ ) to a teacher's stability and well-being. The emotional demands here are the interactions at work that need to be met in accordance with employers' demands and demands to remain professional and mature in meeting student needs.

As a result, teachers are professional educators whose primary task is to educate, guide, direct, train, evaluate and evaluate in formal education, elementary and secondary education. Teachers are responsible for shaping a generation of virtuous people and this is a trust that needs to be fulfilled. Education plays a major role in the development of a nation. The quality of education either directly or indirectly contributes to the formation of a wonderful generation and a sustainable, productive and healthy nation. The quality of excellent education depends on the high productivity of the educators, the teachers.

\section{References}

Abedallah, A. C. M. (2015) The mediating role of burnout on the relationship of emotional intelligence and self-efficacy with OCB and performance. Management Research Review, 38 (1), 2 - 28.

Awang, A. H., Ibrahim, I., Hussain, M. Y., Ramli Z., \& Lyndon, N. (2013). Kualiti dan Prestasi Kerja Graduan Kolej Komuniti: Penilaian oleh Majikan Bandar. Akademika 83 (1), 65-76.

Abraham, R. (1999). Emotional intelligence in organizations: a conceptualization. Genetic, Social, and General Psychology Monographs, 125 (2), 209-224.

Ashkanasy, N. M., and Hooper, G. (1999). Perceiving and managing emotion in the workplace: a research agenda based on neurophysiology. paper presented at the Third Australian Industrial and Organizational Psychology Conference, Brisbane.

Rezvania, A., \& Khosravi, P. (2019). Emotional intelligence: The key to mitigating stress and fostering trust among software developers working on information system projects. International Journal of Information Management , 48, 139 - 150.

Bar-On, R., and Parker, J.D.A. (2000), The Handbook of Emotional Intelligence. San Francisco: JosseyBass. 
INTERNATIONAL JOURNAL OF ACADEMIC RESEARCH IN BUSINESS AND SOCIAL SCIENCES Vol. 10, No. 10, 2020, E-ISSN: 2222-6990 @ 2020 HRMARS

Amalia, B. R., Wahyuni, I., \& Ekawati, E. (2017). Hubungan antara karir dan hubungan karakteristik individu, beban kerja mental, pengembangan karir dah hubungan interpersonal dengna stres kerja pada guru slb negeri Semarang. Jurnal Kesehatan Masyarakat, 5 (5). Retrieved from http://ejournal3.undip.ac.id/index.php/jkm

Newton, C. J., Teo, S., Pick, D., Ho, M., \& Thomas, D. (2016). Emotional intelligence as a buffer of occupational stress. Personnel Review, 45 (5).

Carmeli, A. (2003). The relationship between emotional intelligence and work attitudes, behavior and outcomes. Journal of Managerial Psychology, 18, 788-813.

Chang, C. P., \& Chang, F. J.(2010). Relationships among traditional Chinese personality traits, work stress, and emotional intelligence in workers in the semiconductor industry in Taiwan: Quality Quantity. International Journal of Methodology, 44 (4), 733-748.

Ciarrochi, J. V., Chan, A. Y., \& Caputi, P. (2000). A critical evaluation of the emotional intelligence construct. Personality and Individual Differences. 28(3), 539-561.

Coetzee, M., \& Harry, N. (2013). Emotional intelligence as a predictor of employees' career adaptability. Journal of Vocational Behavior, 84(1), 90-97.

Greenidge, D., Devonish, D., \& Alleyne, P. (2014). The relationship between ability-based emotional intelligence and contextual performance and counterproductive work behaviors: a test of the mediating effects of job satisfaction. Human Performance, 27(3), 225-242.

Dunham, J. (1992). Stress in Teaching 2nd. edition. London: Routledge.

Meisler, G., \& Gadot, E. V. (2012). Perceived organizational politics, emotional intelligence and work outcomes Empirical exploration of direct and indirect effects. Personnel Review. 43(1), 116-135.

Gardner, H. (1983). Frames of mind: The theory of multiple intelligences. New York: Basic Books.

Wan, H. C., Downey, L. A.. \& Stough, C. (2014). Understanding non-work presenteeism: Relationships between emotional intelligence, boredom, procrastination and job stress. Personality and Individual Differences. 65, $86-90$.

Ismail, A., Suh-Suh, Y., \& Ajis, M.. \& Dollah, N. F. (2009). Relationship between Occupational Stress, Emotional Intelligence and Job Performance: An Empirical Study in Malaysia. Theoretical and Applied Economics. 10(539). 3-16.

Min, J. (2014). The Relationships Between Emotional Intelligence, Job Stress, and Quality of Life Among Tour Guides. Asia Pacific Journal of Tourism Research, 19(10), 1170-1190.

Landa, J. M. A., Lo'pez-Zafra, E., Martos, P. B., \& Aguilar-Luzo'n, M. D. C. (2008). The relationship between emotional intelligence, occupational stress and health in nurses: A questionnaire survey. International Journal of Nursing Studies. 45, 888-901.

Sharma, J., Dhar, R. L., \& Tyagi, T. (2015). Stress as a mediator between work-family conflict and psychological health among the nursing staff: Moderating role of emotional intelligence. Applied Nursing Research, 30, 268-275.

Kamaruddin, K. (2007). Tekanan kerja di kalangan guru sekolah menengah. Jurnal Kemanusiaan. 5(2), 104-118.

Karimi L., Leggat S. G., Donohue L., Farrell, G., \& Couper, G. E. (2013). Emotional rescue: the role of emotional intelligence and emotional labour on well-being and job-stress among community nurses. Journal of Advanced Nursing. 70(1).

Mohamad, M., \& Jais, J. (2016). Emotional Intelligence and Job Performance: A Study Among Malaysian Teachers. Procedia Economics and Finance. 35, 674- 682. 
INTERNATIONAL JOURNAL OF ACADEMIC RESEARCH IN BUSINESS AND SOCIAL SCIENCES Vol. 10, No. 10, 2020, E-ISSN: 2222-6990 @ 2020 HRMARS

Maj S. E., \& Ogle, A. D. (2006). Job stress, depression, work performance, and perceptions of supervisors in military personnel. Military Medicine, 171(9), 861-865.

Vijayan, M. (2017). Impact Of Job Stress On Employees' Job Performance In Aavin, Coimbatore. Journal of Organisation \& Human Behaviour. 6(3), 21-29.

Sony, M., \& Mekoth, N. (2016). The relationship between emotional intelligence, frontline employee adaptability, job satisfaction and job performance. Journal of Retailing and Consumer Services. $30,20-32$.

Roring, M. Y., Soegoto, A. S., \& Dotulong, L. (2014). Stres Kerja Dan Lingkungan Kerja Pengaruhnya Terhadap Prestasi Pegawai Pada Biro Umum Setda Provinsi Sulawesi Utara. Jurnal EMBI, 2(3), 1359-1368.

Muniandy, M., \& Kutty, F. M. (2019). Impak Beban Tugas Terhadap Prestasi Kerja Guru Di Maktab Rendah Sains Mara. Jurnal Dunia Pendidikan. 1(1), 9-17.

Rizwan, M., Waseem, A., \& Bukhari, S. A. (2014). Antecedents of Job Stress and its impact on Job Performance and Job Satisfaction. International Journal of Learning \& Development, 4(2), 187283.

Zafar, Q., Ali, A., Hameed, T., Ilyas, T., \& Younas, H. I. (2015). The Influence of Job Stress on Employees Performance in Pakistan. American Journal of Social Science Research. 1(4), 221-225.

Sandra, R. (2015). Konsep Stres Kerja Guru Bimbingan Dan Konseling. Indonesian Institute for Counseling, Education and Therapy (IICET). 1(1), 80-85.

Nart, S., \& Batur, O. (2014). The relation between work-family conflict, job stress, organizational commitment and job performance: A study on turkish primary teachers. European Journal of Research on Education. 2(2), 72-81.

Sharif, S. R. (1991). Pengaruh Faktor Sekolah ke Atas Tekanan Guru. (Unpublished master's thesis). University of Malaya, Kuala Lumpur, Malaysia.

Suandi, T., Ismail, I. A., \& Othman, Z. (2014). Relationship Between Organizational Climate, Job Stress and Job Performance Officer at State Education Department. International Journal of Education \& Literacy Studies. 2(1), 17-28.

Ali, W. U., Raheem, A. R., Nawaz, A., \& Imamuddin, K. (2014). Impact of Stress on Job Performance: An Empirical study of the Employees of Private Sector Universities of Karachi, Pakistan. Research Journal of Management Sciences. 3(7), 14-17.

Yozgat, U., Yurtkoru, S., \& Bilginoglu, E. (2013). Job Stress and Job Performance Among Employees in Public Sector in Istanbul: Examining the Moderating Role of Emotional Intelligence. Procedia Social and Behavioral Sciences, 75, 518-524.

Wu, Y. C. (2011). Job Stress and Job Performance Among Employees In The Taiwanese Finance Sector: The Role Of Emotional Intelligence. Social Behavior And Personality. 39(1), 21-32.

Aman, Z., \& Shukor, K. (2015) Faktor-faktor yang mempengaruhi prestasi kerja dalam kalangan staf sokongan. Paper presented at $2^{\text {nd }}$ International Conference on Management and Muamalah, Selangor, Malaysia.

Corresponding Author: Ashim Mohd Hatta

Nurul-Azza Abdullah, PhD

Email: nurulazza@ukm.edu.my 